\title{
Translating land justice through comparison: a US-French dialogue and research agenda
}

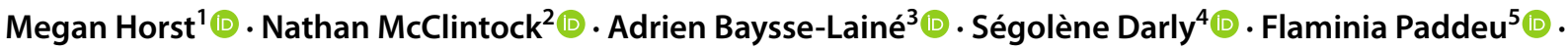 \\ Coline Perrin $^{6} \cdot$ Kristin Reynolds $^{7,8,9}$ (C) Christophe-Toussaint Soulard ${ }^{6}$ (i)
}

Accepted: 19 February 2021 / Published online: 6 March 2021

(c) The Author(s), under exclusive licence to Springer Nature B.V. 2021

\begin{abstract}
In this discussion piece, eight scholars in geography, urban planning, and agri-food studies from the United States (US) and France engage in a bi-national comparison to deepen our collective understanding of food and land justice. We specifically contextualize land justice as a critical component of food justice in both the US and France in three key areas: access to land for cultivation, urban agriculture, and non-agricultural forms of food provisioning. The US and France are interesting cases to compare, considering the differences and similarities in their colonial and agricultural histories, persistent and systemic race and class-based inequities in land access, and the roles of public bodies and social movements. In this paper, we synthesize literature, share reflections, and offer directions for future scholarship, including a broader comparative research agenda. An important difference we found is in the degree of scholarly attention to race and how it mediates access to land. We also observe that few scholars articulate a clear definition of justice in their work, nor do they share a common justice framework. We hope that this paper contributes to a more robust food and land justice framework for the use of scholars, practitioners and activists.
\end{abstract}

Keywords Agriculture $\cdot$ France $\cdot$ Food justice $\cdot$ Land justice $\cdot$ Urban agriculture $\cdot$ United States

\section{Abbreviations}

US United States

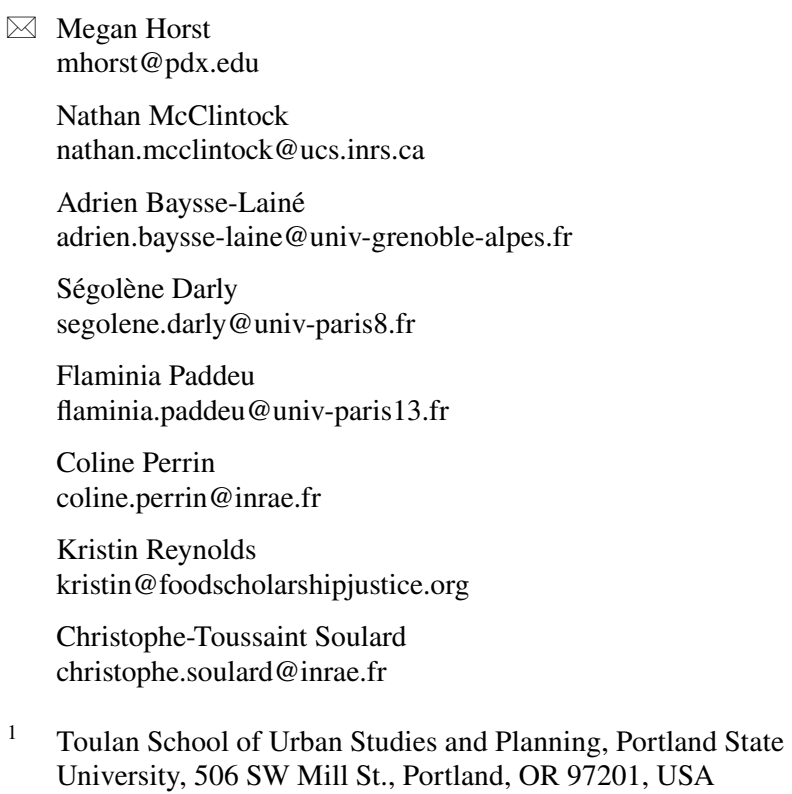

2 Centre Urbanisation Culture Société, Institut national de la recherche scientifique, Montreal, Québec H2X 1E3, Canada

3 Laboratoire Pacte, Centre national de la recherche scientifique (CNRS), 14 avenue Marie Reynoard, 38100 Grenoble, France

4 UMR Ladyss, Université Paris 8 Vincennes Saint-Denis, 2 rue de la Liberté, 93200 Saint-Denis, France

5 Department of Geography, University Sorbonne Paris Nord, Pleiade, 99 avenue Jean-Baptiste Clément, 93430 Villetaneuse, France

6 UMR Innovation, INRAE, CIRAD, Montpellier University, Montpelier, France

7 Independent Scholar, New York, NY, USA

8 The New School, 66 W. 12 Street, New York, NY 10011, USA

9 Yale School of the Environment, 195 Prospect Street, New Haven, CT 06511, USA 


\section{Introduction}

What is land justice? How does it relate to food justice and thus serve as a framework for critical agri-food activism and scholarship? And how might it translate as a critical lens in different countries and in different languages? In May 2018, eight agri-food scholars from the United States (US) and France working in geography, urban planning, and agri-food studies, met in Portland, Oregon, to grapple with these and other questions. In the US, food justice is both an academic framework and a social movement used to identify and struggle against inequities in the food system, while in France, food justice is only just emerging as such. More specifically, the concept of land justice highlights the inequitable access to land, especially by Indigenous people who have been dispossessed of their traditional territory, and by others experiencing marginalization around the intersection of race, class, gender, and other identities. With a few exceptions (Orozco et al. 2018; Safransky 2018; Williams and Holt-Gíménez 2017), however, land justice is often associated with struggles in the so-called 'global South' and is not particularly widespread in either US or French scholarship and activism.

During our time together in 2018, we shared works-inprogress, met with activists and practitioners at peri-urban and urban agriculture sites, and convened a public symposium in an effort to advance land justice as a framework. ${ }^{1}$ In the two years since, we have continued our conversation via email and multiple drafts of this article, a discussion and review piece in which we employ a bi-national, comparative approach to reflect on food and land justice scholarship in the US and France and outline a scholarly agenda. A US-French comparison provides fertile ground for reflection, given the similarities and differences between the two countries. In both, there are significant food and land injustices experienced along racial, class and other intersectional lines. But they differ in how material inequalities manifest, the extent to which these issues are acknowledged, and in terms of the policies and social movements that have emerged in response.

\footnotetext{
${ }^{1}$ Our tour included visits to a farmland incubator on the urban/rural fringe, a community garden cultivated mainly by immigrants and refugees, an urban gardening anarchist collective, and a restaurant with a rooftop garden. The symposium featured two keynote speakers: Dr. Michelle Daigle (Mushkegowuk Cree) who gave a talk called "Resurging Indigenous Geographies through Land-Based Practices," and Eric Holt-Gimenez, former director of the organization Food First, who spoke about the racist history of US agriculture and shared highlights from the edited volume Land Justice (Williams and HoltGiménez 2017). We also invited a panel of practitioners to discuss the challenges and practices of land access in Portland from their diverse perspectives.
}

Given the focus of land justice on access to the land base critical to food cultivation and provisioning, we see value and power in foregrounding the concept in agri-food scholarship and food justice activism in the North. It is important to note that while the language has changed over the years, concern over land tenure and ownership has a long history in Indigenous and Black activism and scholarship (e.g. Dunbar-Ortiz 2007; Gilbert et al. 2002; Nembhard 2014; White 2018), as well as in economic, environmental, and religious social ethics discourse from across the world. We attempt here to connect to that history even as we focus primarily on contemporary land justice issues. We begin our discussion by situating land justice within the wider body of scholarship and activism on food justice. We then briefly make the case for a US-France comparison, before synthesizing our shared reflections on land justice as it relates to three areas of scholarship: access to land for cultivation; urban agriculture; and food provisioning beyond the farm and garden. We selected these three themes, first and foremost, because they are the topics we research. But they also are growing focal areas for social movements in both the US and France, and are thus critical spaces in which land justice holds particular salience as a framework. In each section, we identify similarities and contrasts between the US and France, particularly as they relate to each country's history of colonialism, ongoing race-and class-based disparities, the dominance of the corporate food regime, and the role of government and social movements in fostering food and land justice, then offer potential directions for future research. We conclude the article with a discussion of what we learned through this bi-national exchange, and by offering future directions for comparative land justice scholarship.

\section{Land justice: building on food justice as a social movement and analytical framework}

Land justice, like food justice, frames struggles of resistance and liberation around access to and engagement with land (Daigle 2017; Penniman 2018; Simpson and Bagelman 2018; White 2018; Williams and Holt-Giménez 2017). Both are grounded within a broader context of social, racial, and environmental justice struggles spurred by structural inequities, and thus offer an opportunity to connect food to a variety of intersecting social and racial justice issues, from housing and gentrification to reparations (Reese 2019; Safransky 2014, 2018; White 2018). Since the early 2000s, activists and scholars alike have invoked food justice as a rallying cry to critique both the corporate food regime (Friedmann 2005) and the tendency of the 'alternative food movement', when challenging the industrial agri-food system, to ignore social inequities 
(Agyeman and Alkon 2011; Born and Purcell 2006; Sbicca 2019). Generally nested within the broader fields of critical food studies and agrarian studies, the food justice lens focuses attention on inequities at play in the sphere of production (Minkoff-Zern and Sloatt 2016; Sbicca 2019), such as labor conditions and access to land and other resources, as well as those manifest in the sphere of consumption, such as uneven access to healthy food (Heynen et al. 2012) or the elitism of local food (Guthman 2008). Recent work underscoring inequities in food service (Coplen 2018; Jayaraman 2013; Sbicca 2015) draws much needed attention to the spheres of food distribution, processing, and preparation. Food justice scholars have called for a clearer focus on intersectional social inequities and, more particularly, on dismantling colonialism, classism, racism, white privilege, and white dominance within the movement itself (Bradley and Herrera 2016; Slocum et al. 2016). While much of the food justice scholarship has been situated in the US, French scholars have recently begun to flesh out a more robust food justice research agenda (Hochedez and Le Gall 2016; Paddeu 2015).

Food justice scholarship has also called attention to inequities in land access and to their historical and sociopolitical underpinnings. Cadieux and Slocum (2015) identify land as one of four key nodes around which food justice organizing occurs. While the concept of land justice is often associated with peasants' struggles for accessing land in the global 'South'-for example, the movement for food sovereignty articulated by La Via Campesina (Williams and Holt-Gimenez 2017) - the concept of land justice also has salience in both the US and France, and in other countries in the 'North'. As Carlisle (2014) argues, agri-food scholars must disavow singular, overly romantic characterizations of agriculture and, instead, be sensitive to the histories of genocide, dispossession, slavery, and oppression that have shaped spaces of food production, an attention that others have argued need to figure more prominently in how we understand the establishment of settler nations (Hixson 2013; Pulido 2018) and urban space (Safransky 2018), more generally. In the North American context, part of understanding this is to grasp the extent to which settler colonialism, racial capitalism, and white supremacy all depend on the othering and erasure of Black, Brown, and Indigenous lives and lifeways (Bonds and Inwood 2016; McKittrick 2011; Pulido 2017) in rural and urban areas alike (Dorries et al. 2019; Hugill 2017; McClintock 2018; Porter et al 2020; Safransky 2018; Simpson and Bagelman 2018). As postcolonial scholars and others have shown, considering these intersecting dynamics is as also necessary in France and other European nations as it is in the US. Indeed, even if France or Britain or the Netherlands are not settler nations, their interrelated colonial histories"the intimacies of four continents" (Lowe 2015) -nevertheless continue to shape social relations today in their streets, parks, homes, and workplaces (Darly and McClintock 2017; Hancock 2017; Stoler 2011).

A land justice lens not only pushes us to engage with the ways in which racialized exploitation was foundational to US and French agricultural development, but also to attend to the contemporary challenges facing small-scale and peasant farmers - as well as marginalized urban residents who are involved in food production and provisioning - in accessing and/or owning land in settler colonial settings.

In contrast to the narrower, often apolitical focus on food security (Jarosz 2014) and the 'local trap' characteristic of many local food initiatives (Born and Purcell 2006), food and land justice work privileges analysis of the politicaleconomic dimensions of control over food and the resources needed for its production or procurement. But like food justice work more generally, land justice takes seriously the intersectionality of class, race/ethnicity, gender, and other forms of difference, acknowledging and centering historical, collective social trauma, as well as efforts to undo these inequalities. As Safransky (2018, p. 500) observes,

Political-economic frameworks alone do not give us the tools to capture the powerful feelings of historical loss and injustice associated with urban land struggles, nor do they capture the consciousness, aspirations, and claims of resistance movements on their own terms. In other words, when twenty-first-century movements talk about urban land, they are often not just talking about capital and class but also about race and colonialism.

Land justice calls to rethink land as a commons (Holt Giménez and Shattuck 2011) are therefore not only challenges to the hegemony of corporate food and capitalist property regimes, but also contestations of historical and contemporary structures of white supremacy. We thus imagine land justice, like food justice, as both a radical political goal for activists and a critical analytical framework for agri-food scholarship.

\section{The case for comparing the United States and France}

The US and France are useful cases to compare. They are both nation-states in the so-called 'global North', which offers and much needed complement to the important research on agrarian land justice struggles in the 'global South.' Despite their status as wealthy countries, major racial and social inequities among residents persist in both countries, including inequitable access to land for food cultivation. The US and France today both have racially diverse populations, and intersectional race- and class-based disparities exist in each, inequities that can in many ways be traced 
to the structures of racial capitalism (Melamed 2015; Robinson 2000). In both countries, ongoing struggles by scholars and activities and community leaders for racial justice are met with strong resistance from politicians, intellectuals, and organized groups (Onishi 2021).

Both nations accumulated much of their wealth and power through colonial expansion and agriculture played a central role therein. The founding of the US as a nation-state and its subsequent rise as a global power was grounded in two interlinked 'racial projects' (Omi and Winant 2014): the theft of Indigenous land and the theft of African bodies and labor. Chattel slavery and the plantation agriculture it supported generated much of the nation's wealth, fueling capitalist accumulation well beyond the boundaries of the Southern states (Mann 2001; Baptist 2016). Smallholder agriculture, as well, often relied on the labor of the enslaved (Dunaway 2003). Agriculture and the nineteenth century ideology of Manifest Destiny were inseparable, as the federal government encouraged the westward expansion of a Jeffersonian yeomanry, alongside the genocide and dispossession of diverse Indigenous nations (Hixson 2013). After emancipation, the legacy of slavery endured through Jim Crow sharecropping and the dispossession of Black farmers from their land (Wood and Gilbert 2000). There has been no formal reconciliation process to address either of these two major thefts, and US agriculture continues to depend on the exploitation of migrant labor on stolen land (Minkoff-Zern and Sloat 2016).

France's economic development and transformation into a world power was similarly a function of its colonial projects, which extended literally around the globe, from the Caribbean to Québec, Algeria to West and Central Africa, Madagascar to Indochina and Polynesia (Césaire 2001; Fanon 2004; Stoler 2011). France's capital accumulation was not only dependent on resource extraction, plantation cropping, and mercantile trade in its colonies, but also on slave labor (Cooper 2007; Poulin 1992), a history that the country's imaginary of liberté, égalité, fraternité (liberty, equality, brotherhood) tends to elide. Indeed, slavery was abolished in France's colonies in 1848, only fifteen years before Lincoln signed the Emancipation Proclamation. As in the US, variants of racialized exploitation of colonial agricultural labor continued well into the twentieth century (Robert 1996). Even today, the French Republic comprises overseas départements and territories located in the Atlantic, Indian, and Pacific Oceans, which are home to nearly three million French citizens, many of whom continue to serve as agricultural producers of export products such as sugar, bananas, and rum for French and European markets (Blogowski 2017). These territories are burdened with higher rates of unemployment and poverty, and face relatively greater vulnerability to climate change than does the French métropôle (Ferdinand 2018).
The US and France today share a highly privatized, capitalist system of land ownership and tenure (as compared to countries in the global South where more communal land ownership and usufruct access rights persist). As in other 'post-industrial' nations, only a small percentage of the US and French populations are currently engaged in farming, a dramatic decrease from only a century ago. Large multinational firms dominate the food systems of both countries, controlling large portions of the market, from seed production (e.g. Bayer in the US, following its acquisition of Monsanto in 2018, and Groupe Limagrain in France) to food distribution (e.g. Walmart in the US and Carrefour in France) (Howard 2016). Farmland financialization - the purchase of agricultural land by large investment firms-is on the rise, especially in the US (Gunnoe 2014; Horst 2019), compounding a suite of existing challenges, including high land costs and farmland loss, and creating additional barriers for many small-scale farmers. These challenges are rendered more acute by race- and class-based inequities that can be traced to historical structures of exploitation discussed above. France offers more government intervention and a more robust social safety net, so the problems of class inequities are not quite as acute as in the U.S., but many similarities exist.

Taken together, the similarities between the two countries provide useful grounds for comparing ways in which the concept of land justice might be operationalized in the global North. While the above points to some similarities, there are also major differences between the two nations, in terms of basics like area (France is smaller in area than the state of Texas), population (the U.S. has more than five times the population of France), economic power, and built and natural environment. While both nations have an orientation towards economic growth, they also have differences in terms of the nature of relationships between state, market, and civil society, and the various social movements that have worked to redefine them. For example, France has a larger state, including the proportion of total workforce working for the state, the amount the state pays for goods and services as a portion of the Gross Domestic Product, and the size of the welfare state (Prasad 2005). The US is seen as having a more robust civil society, while France has been called a "civic desert" (Saurugger 2007).

As we argue in the remainder of this article, there is much to be gained from such international comparisons, as they can lead not only to a deeper understanding of each country's individual contexts, norms and values, but can also highlight blind spots in each country's research. This is important, not only in order to strengthen and hone our analyses, but also to foster self-reflexive practice, vital for critical agri-food scholarship. Another key value of cross-national research is the identification of patterns to work towards theorization (Hantrais 2008). In the next sections, we examine land 
injustices in three thematic areas: access to land for cultivation, urban agriculture, and non-agricultural forms of food provisioning. Within each of these areas, we utilize a land justice lens to describe key inequities, including their historical and structural causes in the US and France.

\section{Struggling to access land for food production in the US and France}

In both countries, significant disparities exist among who owns, accesses, and has rights to agricultural land. In the US, white, non-Hispanic people own the vast majority of farmland and generate the vast majority of agriculturerelated wealth (97\% and $98 \%$ respectively). ${ }^{2}$ People of color and women tend to own much smaller farms and generate less income from farming, while Hispanic people comprise around $80 \%$ of farm laborers. Native Americans, meanwhile, retain ownership of only about 55 to 66 million acres of land (only some of that useful for food cultivation), a mere fraction (less than 3\%) of the original 2.3 billion acres they once stewarded (Indian Land Tenure Foundation 2009).

These inequities stem from a long history of colonial and racist agricultural land policy (Horst and Marion 2019). The theft of Indigenous land was integral to the granting of land by the U.S. government to white settlers and the subsequent expansion of Western style agriculture (DunbarOrtiz 2014). ${ }^{3}$ At the same time, states like California and Oregon enacted discriminatory laws which prohibited various people of color, including Black and Asian people, from owning land (Walker 2004). Black farmers were also denied the reparations promised with the abolition of slavery (Reynolds 2002). In addition, the US Department of Agriculture (USDA) has systematically discriminated against Black, Native American, Latinx, and women farmers in its lending and other forms of support for decades. Even years after the USDA settled several Civil Rights lawsuits about this discrimination, farmers of color are still underrepresented in the USDA's county committees, which are responsible for assisting farmers with loan and credit programs, and suffer from a lack of information and support (Hannah-Jones 2019; Minkoff-Zern and Sloatt 2016; Orozco et al. 2018). The long push since the New Deal towards the consolidation, industrialization and corporatization of US agriculture (Horst and Marion 2019) has further exacerbated these inequities in farmland access. The institutionalization of commodity price supports, for example, has benefited largescale agribusiness, but done little for small-scale farmers,

\footnotetext{
$\overline{2}$ We use the term Hispanic here, as opposed to Latinx, given that US Census data is collected using this category.

${ }^{3}$ Married white women could also receive homestead claims.
}

including farmers of color, immigrant farmers, and female farmers (Daniel 2013; Reynolds 2002). It is very difficult for beginning farmers - and even more so for those who face additional systemic barriers described previously-without access to inherited land and significant capital to obtain farmland and thrive in farming in the US.

In France, the government does not collect statistical data on ethnicity or race, and the law in fact makes it difficult to do so. The lack of data not only means a more limited understanding of racial discrimination compared to the US but also may be a limitation for future policy discussions, e.g. around reparations. Nevertheless, inequities exist. During the first half of the twentieth century, migrants fleeing postwar economic crises in neighboring countries could only access the least productive land or land in the most remote areas of France. More recently, farmworkers from Southern and Eastern Europe, North Africa, and the former French colonies have only been able to access under-the-table, temporary jobs as farm laborers. Those who have been able to acquire farmland often feel denigrated and marginalized by local (white) farmers (Lascaux 2019). Romani farmers, in particular, are hindered by local landowners, farmers and public institutions when trying to acquire farmland (Aragau et al. forthcoming; Loiseau 2019). ${ }^{4}$ At the same time, since the middle of the twentieth century, the state has implemented various policies to attract wealthier farmers from Northern Europe; the majority of French farmland acquired by foreigners ( $85 \%$ in 2004 , for example) goes to citizens of the United Kingdom, Ireland, the Netherlands, and Belgium. ${ }^{5}$

There are other intersectional inequities when it comes to access to land, securing tenure, and decision-making, as well. Farmers who do not come from agricultural families (roughly one-third of all new farmers), those from outside the region, and those whose production practices differ from the dominant agriculture of the region, all face exclusion (van der Ploeg et al. 2015). New livestock farmers and market gardeners, for example, struggle to find land in areas where farmland is controlled by the wine industry. As a result, they struggle to find land and secure a loan and become economically viable (Baysse-Lainé 2018; HasnaouiAmri 2018; Perrin and Nougarèdes forthcoming). The devaluation of women's work on French farms has led to female rural migration and the loss of female family members' power in management decisions, even when they own the land (Bessière 2010; Maruani and Meron 2012). As in the US, many young and beginning farmers are hindered by

\footnotetext{
${ }^{4}$ The historically nomadic Romani (or Roma) are a minority living throughout Europe. In France, this population is referred to as gens $d u$ voyage ("travelling people" or "travellers").

5 http://www.terresdeurope.net/agriculteurs-europeens-france.asp.
} 
the high cost of land, a lack of start-up capital, and limited access to information on leasing and buying land; many are unable to turn a profit (Baysse-Lainé 2018).

In both the US and France social movements have made some headway in struggles for land justice, but few examples exist of government interventions supporting this end. In the US, Indigenous communities have fought the theft of their land since colonization began and continue to organize to protect or regain access to their historic lands for food cultivation purposes (Dunbar-Ortiz 2014; Simpson 2017). Black-led farm organizations in the US have also been a consistent voice for land justice, from the abolition movement to organizing to protect Black-owned land, to supporting Black farmer cooperatives and calling for reparations from the federal government for slavery (e.g. Black Urban Growers, National Black Food and Justice Alliance; see Penniman 2018; White 2018). But there has been no significant policy response to return land to Native Americans or to Black descendants of those who were enslaved as a form of reparations. Nor has there been movement towards significant land reform to enable access by low-income producers. While the USDA does fund programs aimed at supporting minority, beginning, and local-serving farmers, ${ }^{6}$ these initiatives are miniscule relative to the support funneled toward the corporate food regime in the form of subsidies and other favorable policies, and investment in agribusiness-oriented research and development (DeLonge et al. 2016; Orozco et al. 2018).

There are some signs that food producers suffering from differing land injustices are working more in solidarity. A diverse coalition including representatives from racial justice activists and organizations representing small-scale, predominantly white farmers recently released a detailed agenda for land reform in their vision for a Green New Deal (Figueroa and Penniman 2020). It remains to be seen whether these ideas gain social and political traction to counter systemic inequities and trends towards corporatization and industrialization.

Compared to the US, access to farmland in France is much more regulated by the state. Les Sociétés d'Aménagement Foncier et d'Etablissement Rural, or French Rural Land Agency (SAFER) is a semi-public body run by agricultural trade-unions and local governments in order to control agricultural land ownership. ${ }^{7}$ It has the right of first purchase

\footnotetext{
${ }^{6}$ For example, the USDA Minority and Women Farmers and Ranchers program: https://www.fsa.usda.gov/programs-and-services/farmloan-programs/minority-and-women-farmers-and-ranchers/index

7 SAFER stands for Société d'aménagement foncier et d'établissement rural, which translates as Land Use and Rural Settlement Corporation. It has been criticized for being dominated by the Federation national des syndicats d'exploitants agricoles (the National Federation of Farmers' Unions), a trade union focused on large-scale and export-oriented agribusiness.
}

of any tract of farmland that goes on the market, with the goal of reselling it to another farmer and protecting it from development. The right to lease agricultural land is also regulated. Land prices and tenure are also controlled via the fermage, a default lease arrangement that is long-term and secure (Baysse-Lainé and Perrin 2018). These complementary policy tools have mediated every land transaction since the 1960s, which helps to explain why farmland has remained cheaper (to buy or lease) in France than in the rest of Western Europe, and why farmland has been dominated by mid-size family farms. Over the past 20 years, however, land access in France has become more difficult, particularly as land speculation has become rampant in periurban settings as holding companies and developers buy up farmland.

Beginning farmers, and those interested in alternative farming practices, are further impacted, as they are rarely selected by SAFER to receive land (Sencébé 2012). These small-scale, agroecologically oriented farmers (most of whom do not come from farming backgrounds) have instead received support from non-governmental groups such as Terre de Liens, a national organization that facilitates access to agricultural land by coordinating a land trust and serving as a non-profit property owner. Over the past ten years it has purchased or facilitated transfer of 5000 ha of land on 200 farms. Another alternative stakeholder is the Confédération Paysanne, a minority farmers' union affiliated with La Via Campesina. Upholding the belief that 'three small farms are better than one larger one,' the group circulates information on land availability and implements local programs to train beginning farmers with small-scale projects to access land (Giorgis and Pech 2017). Like in the US, it remains to be seen whether such organizations can counter the larger powers enforcing inequity.

\section{Possible directions for research on land access}

Social movements pushing for land justice are growing in both countries. Scholars might support this work by contributing to a deeper analysis of how aspiring and beginning farmers in rural (as well as urban) areas differentially experience inequities, given the intersectionality of identities (e.g., race/ethnicity, gender, socioeconomic class). Scholars in both countries might also conduct interviews and case studies on the difficulties experienced by farmers without secure land tenure: transhumant pastoralists, apiculturists, aspiring farmers-in-training, seasonal farm workers, or socalled 'nomadic farmers' (Soulard 2014). Such research should incorporate structural analyses of ethno-racism and capitalism, and draw clearer connections between agriculture and (settler) colonialism, racial capitalism, and patriarchy. In the US, for example, more intersectional analysis is needed on Native American food production and provisioning efforts, including efforts to retain and regain access to 
their historical lands. In France, more work is needed on understanding the experiences related to land justice among members of Romani communities, immigrants, and migrant agricultural workers (Aragau et al. forthcoming). Attention to French colonialism would be an opportunity for reconsidering the right to the land of Black and Indigenous people in overseas départements and territories such as New Caledonia, La Réunion, French Guiana, Guadeloupe, and Martinique (Palisse and Davy 2018), while also fostering a relational understanding of the experience of migrants and immigrants from France's former colonies. In addition, more historical work is needed to clarify and better theorize the connections between French colonial agriculture and racial capitalist economic development of metropolitan France, perhaps by bringing a vast body of excellent empirical studies (see, among others, Filipovich 2001; Moitt 2001) into conversation with more theoretical work in political ecology, agrarian studies, decolonial ecology, postcolonial and Black diaspora studies (Ferdinand 2019; King 2019; Poulin 1992; Stoler 2011). The same suggestion holds true for work on US states/territories in the Pacific and Caribbean (Hawai'i, Guam, Commonwealth of the Northern Mariana Islands, Puerto Rico, and the US Virgin Islands). Additionally, in both countries, more work is needed to identify which government interventions - or other non-state models - might effectively counter and thoughtfully weight justice concerns in a way that would garner sufficient public support.

\section{Urban agriculture in New York and Paris}

Land justice is also a relevant lens to apply to urban agriculture (i.e., urban gardening, farming, or livestock husbandry). Scholars and practitioners alike argue that urban agriculture is not only a strategy for increasing local access to healthy food, but also hold potential social justice and environmental benefits (Horst et al. 2017). There is a fast-growing body of critical urban agriculture scholarship in the US (e.g., McClintock 2018; Reese 2019; Reynolds 2015; Safransky 2018; Sbicca 2019; White 2018), much of which centers questions of food justice. Research on urban agriculture in France (and Europe, more broadly), on the other hand, has tended to be more descriptive than critical, though this is beginning to change (Darly and McClintock 2017; Hochedez and Le Gall, 2016; McClintock and Soulard 2018; Paddeu 2016; Tornaghi and Certomà 2018). In both countries, land justice as an analytical framework remains little-developed in urban agriculture scholarship (see Safransky 2018, for an exception). Land access and tenure are nevertheless prominent barriers to the continuation and expansion of urban agriculture, particularly among economically and/or socially marginalized communities.
Recent trends in each country's biggest cities-New York City and Paris-offer insights into the connections between urban agriculture and issues of food and land justice. Both New York and Paris have long histories of food production. In New York, this history spans the nineteenth century market-oriented truck farms and dairies, World War I and II-era government sponsored 'Victory Gardens', the establishment of community gardens on vacant lots in the 1970s, and 1980s to the subsequent decline in support for city farming and gardening as real estate values rose (Lawson 2005; HaydenSmith 2007; Reynolds and Cohen 2016). In Paris, nineteenth century market gardens and dairies gave way in the early twentieth century to worker gardens (jardins ouvriers), and family allotment gardens (jardins familiaux) after World War II. During the 1970s and 1980s, allotment gardens, impacted by intense urban development, nearly disappeared from the Parisian inner core, but remained an important asset of the working class in the surrounding, left-leaning municipalities. New forms of urban agriculture appeared in the late 1990s with the development of community gardening and 'social farming' (i.e., community-oriented or community-supported commercial farms) (Freidberg 2009; Weber 1998).

More recently, both New York and Paris have experienced a resurgence in urban agriculture, with a diversity of actors, forms and purpose. In the US, urban agriculture practitioners include individuals and households, community-based and non-profit organizations, schools, churches, and for-profit/ entrepreneurial actors. They use a range of practices, from rooftop gardening and animal husbandry (e.g. chickens, bees) to traditional community gardens, market gardens, and communal orchards and "food forests." Communitybased and nonprofit organizations rarely have their own land, and often lease or informally occupy vacant public land, school, parks, lands donated by churches, and vacant or under-utilized commercial or industrial land (McClintock 2014). In New York City, two recent studies identified over 1500 community and school gardens, nearly 900 of which produce food (Altman et al. 2014; Cohen et al. 2012). A longstanding challenge for many of these gardens and farms has been insecure land tenure (Reynolds and Cohen 2016). Numerous scholars and activists have argued that permanent land protection is critical for urban agriculture to play a role in food and land justice, yet, as of this writing, local legislators in New York have not passed significant policy to address that core issue (Held 2018).

Another concern relates to the question of who benefits from urban agricultural projects. While many urban agriculture projects in the US have been led by people of color, particularly those focusing improving food access and selfdetermination in low income communities and communities of color, it is more often than not a growing cadre of white, middle-class urban agriculturalists tend to be recognized as 'new urban farmers' or new 'innovators'; this 
disproportionate attention ignores the efforts of low-income urban agriculturalists and farmers of color, and also perpetuates material disparities (Reynolds 2015). In New York City, for example, white-led organizations have had greater access to land, funding, and access to policymakers than those led by People of Color (ibid). This has exacerbated a third challenge in the US, which is urban agriculture's enmeshment with another land justice concern: gentrification (Horst et al. 2017). In New York and other major US cities, urban agriculture, like other 'green amenities', contributes to rising property values and subsequently to the displacement of lower income renters and people of color-the very communities that justice-oriented urban agriculture groups may be intending to serve.

Scholars have noted similar inequities in France, showing, for instance, how new forms of collective gardens emerge in gentrified neighborhoods while ignoring the role of working class dwellers in their past and present history (Adam and Mestdagh 2019). In Paris, for example, the lack of permanent land tenure for gardeners undermines low-income gardeners' efforts to maintain a place not only for leisure and social activities, but also for food provisioning (Pourias et al. 2016). In response to the recent rise of spontaneous collective gardens on vacant urban lots and brownfields, the City of Paris (and many surrounding municipalities) granted legal status to the gardens via the Main Verte program, which provides land access and technical assistance to gardeners, but only if gardeners agree to a temporary tenancy agreement valid only until the lots are needed for urban development (Demailly and Darly 2017). This model stands in stark contrast to the historical worker gardens and family allotment gardens, which were rooted in the political idea that those who grow food should have secure and permanent access to land (Weber 1998).

Alongside collective gardening, there has been a swift rise in high-tech, for-profit, commercial urban agriculture in both cities over the past five to eight years (Reynolds and Darly 2018). These projects, which include photogenic, indoor hydroponic systems and rooftop greenhouses, are flourishing as policy changes supportive of urban agriculture are taking place at the municipal and national levels. For example, the 2018 US Farm Bill included the creation of an Office of Urban Agriculture and Innovative Production (Agricultural Improvement Act of 2018) to support urban agriculture practices, including rooftop farms, "high-tech vertical technology farms," and other types of emerging food production practices (Reynolds 2019). ${ }^{8}$

\footnotetext{
${ }^{8}$ H.R. 2-115th Congress: The Agricultural Improvement Act (2018). United States Congress; Sect. 7212. Urban, indoor, and other emerging agricultural production research, education, and extension initiative. Retrieved from: https://www.govtrack.us/congress/bills $/ 115 / \mathrm{hr} 2 /$ text.
}

This evolution may be welcome in the minds of many practitioners and advocates who have long demanded that policymakers and the wider public take urban agriculture seriously, as both a legitimate use of city land and a legitimate form of agriculture (see Smit et al. 1996). However, the fact that policy is emerging just as commercial and hightech urban agriculture is on the rise underscores the need for policymakers to understand, irrespective of form, the role that white privilege and/or neoliberalism play in governance of urban agriculture and land use, and how this relates to questions of social justice, including access to land. For example, the high-tech commercial urban agriculture sector in New York City and Paris tends to be led primarily by white people, and narratives surrounding the expansion of such activities often emphasize their purported "win-win" contribution to both urban food security and profit-making potential (Reynolds and Darly 2018). In France, highlyskilled, white entrepreneurs, who have been successful in attracting investors and accumulating assets, are advocating to be formally recognized by the state as "professionals" and are shifting policy discussions to focus more on commercial production. At the same time, recent proposals in New York City for municipal-level policy changes pertaining to urban agriculture have led to tense debate during public hearings, as representatives from community-based urban agriculture groups voice their concern that low-income communities and communities of color have been overlooked in the formulation of policy proposals they claimed prioritized newer forms of commercial urban agriculture (ibid). While subsequent proposals have taken a broader view of urban agriculture and its potential contribution to justice-oriented issues, including increasing access to healthy food and economic opportunities in lower-income communities, a land justice frame can guide deeper questions about which voices are represented, and which issues are given priority, in urban agriculture policy formulation and resulting access to land and other resources.

\section{Possible directions for research on urban agriculture}

These views of urban agriculture in New York and Paris suggest that insecure land tenure, structural inequities, entanglement with gentrification, and the rising prominence of high-tech urban agriculture all challenge urban agriculture's potential contributions to food and land justice. They also point to potential future research directions that might center land justice within urban agriculture scholarship. In both contexts, land use planning pertaining to urban agriculture is one among a host of evolving policy issues. Given the place of high-tech urban agriculture in the development of commercial urban agriculture in both the US and French contexts, scholars might illuminate the opportunities and constraints that exist for members of historically marginalized 
communities to benefit from, and lead, this new sector. Scholars can also reflect on the divide between not-forprofit and commercial urban agriculture in policymaking, land access, and opportunities for workers. Another angle of research includes articulating coherent land use policies at city, regional, state, and national scales in order to achieve more equitable urban agriculture.

\section{Urban food provisioning beyond the farm and garden}

In addition to agricultural and horticultural production, a range of other types of food provisioning exist in rural, suburban and urban settings, including hunting, fishing, trapping, foraging, growing edibles on vacant land, scavenging, gleaning, dumpster diving, and even stealing from major food retailers. Just as agri-food scholars should be wary of conflating "local" with "just" (Born and Purcell 2006), we should be wary of reducing food production and provisioning to rural farming and urban agriculture. The relative absence of such provisioning activities in critical agri-food scholarship may relate to the way scholars and practitioners describe the food system in terms of various nodes: production, processing, distribution, retail, consumption, and waste. In characterizing a food system in such a way, 'production' conjures up visions of cultivation, sowing, and harvest, and to a lesser extent, livestock husbandry. ${ }^{9}$ If we embrace food and land justice as objects of struggle and a banner under which to organize and as a scholarly lens of analysis, however, it is important to also consider food provisioning that occurs beyond the farm or garden. And just as access to land impacts people's ability to cultivate food in the field, land justice is a central concern for many of these non-agricultural forms of food provisioning.

A large body of literature on Indigenous foodways has emerged in anthropology, Indigenous studies, and political ecology (Hoover 2017; Norgaard 2020), some of which draws on the food justice and food sovereignty frames widely used by critical agri-food scholars (Daigle 2017). The food justice literature itself, however, has rarely engaged with urban provisioning of this sort, even as it has focused largely on unequal and racialized access to healthy food (Agyeman and Alkon 2011; Reynolds and Cohen 2016; Horst et al. 2017; Sbicca 2018). A growing body of research on foraging and scavenging has tackled issues such as food (in)security (Synk et al. 2017; McLain et al. 2017) and food safety (von

\footnotetext{
9 Though we use 'production' in the broader Marxian sense employed in agrarian political economy - that is, the production of exchange value through labor - these activities are often ignored because they lie largely outside of monetary exchange and are externalized as forms of social reproduction.
}

Hoffen et al. 2014), but rarely through a food justice lens; French scholars, we find, have paid little attention to diverse food provisioning practices in cites, with a recent exception of Paddeu (2019)'s study of informal practices of "food collecting" of both edible biological resources and food waste in urban, suburban, and peri-urban contexts in France.

There are therefore numerous reasons, from a land justice perspective, to look beyond the farm and garden to diverse "patterns of gathering" (Shackleton et al. 2017). First, nonagricultural, non-capitalist forms of food provisioning are central to Indigenous food sovereignty and resurgence in North America (Daigle 2017; Simpson 2017; Simpson and Bagelman 2018). As such, understanding them is critical to the study and pursuit of food and land justice. Food provisioning is important to other marginalized groups, as well. For example, recent migrants in peri-urban areas often depend more on the harvest of wild natural resources than do longtime residents who can invest more in urban agriculture and private spaces where they have established networks and rights of access (McLain et al. 2017; Poe et al. 2014). Environmental contamination-and regulatory efforts to protect the public from such contamination-thus disproportionately impact these groups (Goodling 2019).

At a more fundamental level, these non-agricultural forms of provisioning run up against the capitalist property regimes that mediate access to urban land. Provisioning practices in cities have been threatened not only as a result of the physical expansion of the built environment and the concomitant destruction of the ecologies that hunters, fisherfolk, foragers, and others depend on for food, but also due to the regulation and enforcement of private property rights. Individual property rights translate materially as deeds and leases, fences, security guards, and regular patrols, and as changes in landscape design (Blomley 2004; Hurley et al. 2015). Foraging and other forms of provisioning, on the other hand, has long been associated with common property regimes (Svizzero 2016) which are scarce in the (post)colonial and capitalist world-especially in cities in the 'global North' where they are threatened by privatization and other forms of enclosure. Many provisioning practices were rendered illegal in cities via municipal regulations based on modernist and hygienist notions of progress that discursively framed some of these practices both as 'rural' and 'backwards', and thus unacceptable land uses in urban area, a history that they share with urban livestock husbandry and other forms of urban agriculture (Brinkley and Vitiello 2014). ${ }^{10}$ As these practices were excluded from urban spaces and reimagined-and regulated - as 'rural', they became less and less

\footnotetext{
${ }^{10}$ Urban agriculture and urban livestock has slowly been able to cast off these distinction, but it has not been without considerable contestation.
} 
common and eventually viewed purely as recreational activities or hobbies, despite their potential contribution to urban diets and foodways.

In the US and other settler societies, the advent and imposition of private property regimes on land that was once managed collectively led to the destruction of Indigenous food systems, and continues to create important barriers to the resurgence of traditional food provisioning practices such as hunting, fishing, and gathering for Indigenous people and settlers alike (Coulthard 2014; Mihesuah and Hoover 2019; Simpson and Bagelman 2018). In concert with the genocide and removal of Indigenous tribes from their territory onto reservations, the imposition of a cadastral grid system onto the land allowed for its division into individual parcels or allotments that could be distributed to white, mostly male settlers (Shoemaker 2003) to 'improve' through agriculture. This "racial regime of property" (Bhandar 2018) served not only as the prerequisite enclosure of the commons necessary for capitalist accumulation, but also to enshrine white supremacy via land and property relations, both discursively and materially (Blomely 2004; Pulido 2017, 2018).

The often racialized reconfiguration of space via urbanization - and capitalism, more broadly-forces food gatherers of all racial and ethnic backgrounds to be more adaptive, innovative, and knowledgeable about alternative sites, species, and uses. Practices such as foraging, gathering, and hunting/trapping, have the potential to challenge hegemonic notions of property rights and enclosure. Food provisioners often are quite creative in circumventing and resisting ownership patterns, land tenure, and land management strategies that create barriers to their practices (McClintock et al. 2020; Paddeu 2019). For Indigenous scholars, such strategies are not only examples of resistance to the imposition of settler colonial legal and property regimes, but respect and strengthen the multiple, nested sovereignties mediating Indigenous relationships to food, land, and community (Coulthard 2014; Daigle 2017; Simpson 2017). These diverse practices reveal insights about land and space, food policies, management practices, and the transformation of space and place within the context of racial capitalism (Bledsoe et al. 2019).

Like urban agriculture, urban foraging and scavenging can both challenge and support structural racism and class inequalities, underscoring the need to bring a critical food and land justice lens to their practice and study. Foragers and scavengers who gather edible weeds or divert flows of food waste may actually reproduce power relations rather than dismantling hierarchies of power and privilege. For example, a member of a hip, local non-profit organization that collects unsold organic food in Paris, acknowledged in a recent interview that the organization's efforts have actually reduced food gathering opportunities for independent gleaners, who are now suddenly left with "empty" dumpsters. ${ }^{11}$ Such examples thus reiterate the importance of concerns raised by critical food scholars around inequities, color-blindness, and class distinctions in urban agriculture and other alternative food movements.

\section{Possible directions for research on urban foraging and other forms of provisioning}

As McClintock (2018) notes, we should remain vigilant that scholarship on white, Euro-American practices of cultivation (i.e., land-based agriculture) does not contribute to the erasure of non-white epistemologies and practices. Scholars can address the lack of attention in US and French scholarship to diverse forms of food provisioning through substantive engagement at several levels. First, acknowledging historical trauma (for example, the repression of Native American foodways) and undoing persistent race, gender, religious, citizenship, and class inequities are fundamental to reclaiming a right to collect wild food (Paddeu 2019). Scholars might also examine foraging, gathering, and hunting/trapping as "pericapitalistic practices", both inside and outside of capitalism (Tsing 2015). Relatedly, scholars might reflect on how "patterns of gathering" (Shackleton et al. 2017) are impacted by privatization and loss of the commons as well as through neighborhood changes of socio-demographics, values and landscapes. How provisioning practices and their reconfigurations articulate with larger rural and urban place-based dynamics, such as governance and property regimes, is also a critical area for examination. As emphasized in other sections of this article, scholars should also reflect on how different gatherers are affected unequally, due to longstanding inequities and systems of oppression. Uneven systems of power may pave the way to unexpected and fundamentally ambivalent alliances through "latent commons" within the "ruins of capitalism" (Tsing 2015), as evidenced by a long history of Black and Indigenous commons emerging in these spaces (Bledsoe et al 2019). Tracing the genealogy and geographies of such commoning practices is certain to generate new insights.

\section{Conclusion: what is lost in translation and what is gained via comparison and exchange?}

In this paper, we have synthesized highlights of existing scholarship on three areas at the intersection of land and food justice both outside and within cities: agricultural land access, urban agriculture, and diverse forms of provisioning. By comparing and contrasting the US and France, we gained

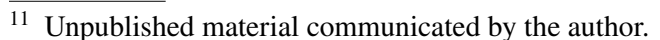


insights that can contribute to the ongoing theorization of land justice. Rethinking access to land in the city and beyond demands thinking beyond basic issues of land availability and engagement in deeper-reaching political debates over race, class, space, and justice. Understanding property relations, and confronting the longstanding inequities and systems of oppression that imposed these relations is also key (Safransky 2018). By honing our perspectives and clarifying our conception of land justice this way, scholarship can better contribute to intellectual debates, but also to the tactical levers of action - both in formal policy spheres and social movements-needed to realize a more just food system.

Our review synthesizes some of the many ideas and perspectives we shared during our week together and in our exchanges since then. This has not always been straightforward, as some things simply do not translate. Indeed, from the beginning, we even had a hard time coming up with a good French translation for the concept 'land justice'. The most obvious parallel, justice foncière, seemed to miss something essential, as it evokes a narrow, juridical focus on land tenure, while the English term, particularly for US scholars and activists, resonates with historical connections to racial and environmental justice struggles (Safransky 2018).

Despite this early definitional challenge, our bi-national comparison has proven fruitful, as it has revealed several key differences, as well as points of overlap, in food and land justice scholarship and activism in the US and France. Of particular note, there are similarities when it comes to the role that agriculture played in the colonial histories of the US and France. In both countries today, marginalized farmers and food cultivators lack affordable and secure land tenure, whereas governmental (and quasi-governmental) involvement in the agricultural land market and attempts by civil society to address land access barriers differ markedly. In France, the government plays a stronger role and has perhaps enhanced access compared to the US, but many similar inequities exist. When it comes to urban agriculture, there appear to be more similarities than differences, as scholars and activists in both France and the US share concerns over insecure land tenure and who benefits, as well as over urban agriculture's entanglement in gentrification and increasing attention to high-tech, commercial production. In terms of food provisioning beyond the farm and garden, the US and France are nearly identical in the lack of scholarly attention paid to practices such as gleaning, foraging, gathering, hunting, and fishing in cities, but stand to learn from a rich scholarship on common property regimes and Indigenous foodways.

Perhaps the most important difference we found relates to the degree of scholarly attention to race and how it mediates access to land. From the US perspective, current approaches to land justice tend to be explicit in their attentiveness to racial inequities, whereas French approaches tend to focus around fairer allocation of land sales and leasing. As we note above, this is due, in part, to the fact that racial statistics are not collected in France. The resulting lack of data, along with the dominant cultural imaginary of a liberal democracy that is colorblind, allows whites, in particular, to remain blind to and even deny racial disparities. While such denial is also widespread in the US in mainstream public discourse, critical agri-food scholars tend to grapple with race more than their French counterparts do. However, the global protests following George Floyd's murder seem to be spurring important conversations and reckoning in France (Onishi 2020).

Something else that became apparent through our US-France comparison of food and land justice activism and scholarship is that few scholars articulate a clear definition of justice in their work, nor do they share a common justice framework. Furthermore, critical food scholars have not consistently unpacked the varying concepts of distributional justice (including corrective justice) and procedural justice (including recognition and participatory forms of justice). Another problem is that there often is an assumption of Western theories of justice, and an erasure or ignorance of, for example, Black and Indigenous theories of justice and rights to land, and of decolonial studies (Reynolds 2020). This ultimately may have implications for what land justice 'looks like' in practice: from the US perspective, land justice tends to be employed more as a corrective addressing a broader historical context, whereas from the French perspective, it tends to focus more narrowly on fairer allocation of land on the market. Our comparison also allowed us to begin delineating future directions for critical agri-food scholarship for each of the three themes addressed above. Rather than restating these, we emphasize a key point of synthesis: intersectional considerations around race and class must figure centrally and incorporate a more relational analysis of (settler) colonialism and its legacies and persistent logics and practices.

While our focus in this paper was on the US and France, our approach and insights can be expanded into an integrated international comparative research agenda. Many of the questions and points discussed here also pertain to other areas of the so-called 'global North'. We encourage future researchers to take forward our comparison and add their own perspectives, furthering the analytical meaning of the comparative exercise. For example, Indigenous-led food sovereignty efforts in Canada and Australia can be points of reflection for similar efforts in the US (Daigle 2017; Porter et al. 2020). There are also long histories of urban gardening on allotment gardens in Germany and Austria, among other countries (Lorbek and Martensen 2015; Tornaghi and Certomà 2018) that may offer US and French practitioners ideas of how to better address the need for permanent land access while German and Austrian scholars might 
reflect on whether such interventions are actually fostering more equitable land access across racial and socioeconomic divides. Similarly, work on "quiet sustainability" practices beyond the farm and garden that have been studied in Eastern Europe (e.g., Smith and Jehlička 2013), may provide insights for US and French scholars, who have tended to ignore such diverse forms of provisioning.

We recognize a number of limitations to our discussion. Our hope is that by acknowledging them, we might flag them as additional areas for future discussion and research. First, we focused on two countries that may not be places where the best examples of food and land justice movements and analysis are flourishing. Second, we focused on issues on the US and French mainlands, and aside from calling for a relational approach to incorporating their overseas (colonized) territories, did not discuss them in detail. Third, we focused on aspects of farmland access, urban agriculture, and nonagricultural provisioning, but did not give attention to other aspects of the food system, such as labor, distribution, and consumption. Nor did we give deep attention to how other aspects of governance, such as labor laws and social safety nets, interact with land justice. Our choice in this paper was to build on our existing collective expertise, but examining other aspects of the food system would certainly shed additional light on food and land justice struggles. A final limitation stems from our own positionalities as mainly white, European or European-descended scholars. We have advocated here for embracing land justice as a useful analytical and organizing frame for shared and intersectional struggle against all systems of oppression. We recognize, however, that some Indigenous and racialized scholars, for example, may take issue with this broad umbrella approach, and argue instead for a narrower focus on specific issues of importance to Indigenous, Black, and Brown communities. We also acknowledge some further tensions in witting about justice. On the one hand, we feel compelled to use our positions of relative privilege and authority to expand scholarly attention, particularly to our fellow white scholars, to systemic injustices. We have intentionally cited Black and Indigenous scholars, as one way to bring in more lived experience to the analysis. On the other hand, we grapple with two unresolved questions: First, how can white scholars and activists go about doing land and food justice work without doing more harm than good? Second, how can white scholars and activists leverage our privileges in the space of food and land justice? We wonder if that might mean, in addition to or instead of publishing ourselves, moving aside and giving up space and resources to those who have most directly been impacted by our oppressive systems. We raise these questions here knowing we are not solving them, but as important points of reflection for future contributors to this ongoing discussion.
Despite these shortcomings, we feel land justice is particularly salient at this moment in history. In the US, the average age of farmers is nearing 60 years old and a significant transfer of ownership of farmland is underway, representing a threat of a ramp-up of corporate land takeover, further consolidation of white land ownership, and/ or a window of opportunity to increase more equitable land access. As we revise this article in late 2020 and early 2021 , the US and France, with the rest of the world, are scrambling to respond to the global COVID-19 pandemic. At the same time, millions worldwide have taken to the streets to decry anti-Black police violence and white supremacy. White supremacists continue to exert their privileges, from the takeover of the US Capitol in January 2021 to backlash from French intellectuals to calls for attention to the ongoing impacts of colonialism and to the engagement of critical race theory (Onishi 2021). The pandemic and its associated economic impacts, as well as the backlash against the mobilization for Black lives, may exacerbate many of the issues of land justice we have explored in this paper. At the same time, new opportunities are arising from the current historical conjuncture. Interest in local food systems, urban gardening, and self-provisioning is surging. Land justice activists are advocating that land justice-focused strategies should be part of economic stimulus and recovery interventions. We are hopeful that our discussion here might contribute to thinking how land justice can be foregrounded in both the immediate and longer term.

Acknowledgements The research has been supported by Portland State University, Oregon, USA, and has received funding from the French National Research Institute for Agriculture, Food, and the Environment (INRAE), from the People Programme (Marie Curie Actions) of the European Union's Seventh Framework Programme (FP7/20072013) under REA grant Agreement n. PCOFUND-GA-2013-609102, through the PRESTIGE programme coordinated by Campus France, and from the French National Research Agency (ANR) [JASMINN Project ANR-14-CE18-0001]

\section{References}

Adam, Mathieu, and Léa. Mestdagh. 2019. Invisibiliser pour dominer L'effacement des classes populaires dans l'urbanisme contemporain. Territoire en mouvement. Revue de géographie et aménagement. https://doi.org/10.4000/tem.5241.

Agyeman, Julian, and Alison Hope Alkon. 2011. Cultivating food justice: Race, class, and sustainability. Cambridge, MA: MIT Press.

Altman, Lee, Liz Barry, Martin Barry, Kaja Kuhl, Philip Silva, and Barbara Wilks. 2014. Five borough farm II: Growing the benefits of urban agriculture in New York City. New York: Design Trust for Public Space.

Aragau, Claire, Ségolène Darly, Camille Hochedez, Julie Le Gall, and Monique Poulot. Forthcoming. L'activité agricole, une ressource pour l'ancrage des étrangers? Recomposition du lien agriculture migration. Cahiers Agricultures.

Baptist, Edward E. 2016. The half has never been told: Slavery and the making of American capitalism. London: Hachette UK. 
Baysse-Lainé, Adrien. 2018. Terres nourricières. La gestion de l'accès au foncier agricole en France face aux demandes d'alimentation locale. Enquêtes dans l'Amiénois, le Lyonnais et le sud-est de l'Aveyron. Doctoral thesis, Université de Lyon, France.

Baysse-Lainé, Adrien, and Coline Perrin. 2018. How can farmland management styles favor local food supply? A case-study in the Northern Larzac plateau (France). Land Use Policy 75: 746-756.

Bessière, Céline. 2010. De génération en génération. Arrangements de famille dans les entreprises viticoles de Cognac. Paris: Editions Raisons d'agir.

Bhandar, Brenna. 2018. Colonial lives of property: Law, land, and racial regimes of ownership. Durham, NC: Duke University Publishing.

Bledsoe, Adam, Tyler McCreary, and Willie Wright. 2019. Theorizing diverse economies in the context of racial capitalism. Geoforum. https://doi.org/10.1016/j.geoforum.2019.07.004.

Blogowski, A. 2017. Les échanges de produits agricoles et agroalimentaires dans les départements d'outre-mer, Les notes de l'Observatoire de l'économie agricole dans les DOM No. 6. Montreuil: ODEADOM.

Blomley, Nicholas. 2004. Unsettling the city: Urban land and the politics of property. London: Routledge.

Bonds, Anne, and Joshua Inwood. 2016. Beyond white privilege: Geographies of white supremacy and settler colonialism. Progress in Human Geography 40: 715-733.

Born, Branden, and Mark Purcell. 2006. Avoiding the local trap: Scale and food systems in planning research. Journal of Planning Education and Research 26: 195-297.

Bradley, Katharine, and Hank Herrera. 2016. Decolonizing food justice: Naming, resisting, and researching colonizing forces in the movement. Antipode 48 (1): 97-114.

Brinkley, Catherine, and Domenic Vitiello. 2014. From farm to nuisance: Animal agriculture and the rise of planning regulation. Journal of Planning History 13 (2): 113-135.

Cadieux, Kirsten Valentine, and Rachel Slocum. 2015. What does it mean to do food justice? Journal of Political Ecology 22: 1.

Carlisle, Liz. 2014. Critical agrarianism. Renewable Agriculture and Food Systems 29: 135-145.

Césaire, Aimé. 2001. Discourse on colonialism. New York: New York University Press.

Cohen, Nevin, Kristin Reynolds, and Rupal Sanghvi. 2012. Five borough farm: Seeding the future of urban agriculture in New York City. New York: Design Trust for Public Space.

Coplen, Amy K. 2018. The labor between farm and table: Cultivating an urban political ecology of agrifood for the 21st century. Geography Compass 12 (5): 12370.

Cooper, Barbara T. 2007. Race, gender, and colonialism in Anaïs Ségalas's Récits des Antilles: Le Bois de la Soufrière. L'Esprit Créateur 47 (4): 118-129.

Coulthard, Glen Sean. 2014. Red skin, white masks: Rejecting the colonial politics of recognition. Minneapolis, MN: University of Minnesota Press.

Daigle, Michelle. 2017. Tracing the terrain of Indigenous food sovereignties. Journal of Peasant Studies 46: 297-315.

Daniel, P. 2013. Dispossession: Discrimination against African American farmers in the age of Civil Rights. Chapel Hill: The University of North Carolina Press.

Darly, Ségolène., and Nathan McClintock. 2017. Introduction to urban agriculture in the neoliberal city: Critical European perspectives. ACME: An International Journal for Critical Geographies 16 (2): 224-231.

DeLonge, Marcia S., Albie Miles, and Liz Carlisle. 2016. Investing in the transition to sustainable agriculture. Environmental Science and Policy 55: 266-273.
Demailly, Kaduna-Ève, and Ségolène. Darly. 2017. Urban agriculture on the move in Paris: The routes of temporary gardening in the neoliberal city. ACME: An International Journal for Critical Geographies 16 (2): 224-231.

Dorries, Heather, David Hugill, and Julie Tomiak. 2019. Racial capitalism and the production of settler colonial cities. Geoforum. https ://doi.org/10.1016/j.geoforum.2019.07.016.

Dunaway, Wilma A. 2003. Slavery in the American Mountain South. New York: Cambridge University Press.

Dunbar-Ortiz, Roxanne. 2007. Roots of resistance: A history of land tenure in New Mexico. Norman: University of Oklahoma Press.

Dunbar-Ortiz, Roxanne. 2014. An indigenous peoples' history of the United States. Boston: Beacon Press.

Fanon, Joby. 2004. Frantz Fanon: de la Martinique à l'Algérie et à l'Afrique. L'Harmattan.

Ferdinand, Malcolm. 2018. Subnational climate justice for the French Outre-mer: Postcolonial politics and geography of an epistemic shift. Island Studies Journal 13 (1): 119-134.

Ferdinand, Malcolm. 2019. Une écologie décoloniale. Penser l'écologie depuis le monde caribéen. Paris: Le Seuil.

Figueroa Meleiza, and Leah Penniman 2020. Land access for beginning and disadvantaged farmers. Green New Deal Policy Series, Data for Progress. http://filesforprogress.org/memos/land_acces s_for_beginning_disadvantaged_farmers.pdf

Filipovich, Jean. 2001. Destined to fail: Forced settlement at the Office du Niger, 1926-45. Journal of African History 42: 239-260.

Freidberg, Susanne E. 2009. Fresh: A perishable history. Cambridge: Harvard University Press.

Friedmann, Harriet. 2005. From colonialism to green capitalism: Social movements and emergence of food regimes. Bingley: Emerald Group Publishing Limited.

Gilbert, J., G. Sharp, and M.S. Felin. 2002. The loss and persistence of black-owned farms and farmland: A review of the research literature and its implications. Journal of Rural Social Sciences 18 (2): 1 .

Giorgis, Diane, and Michel Pech. 2017. S'installer en agriculture: Pour un véritable accompagnement des paysans de demain. Paris: Charles Léopold Mayer.

Goodling, Erin. 2019. Urban political ecology from below: Producing a "peoples' history" of the Portland Harbor. Antipode.

Gunnoe, Andrew. 2014. The political economy of institutional landownership: Neorentier society and the financialization of land. Rural Sociology 79 (4): 478-504.

Guthman, Julie. 2008. Bringing good food to others: Investigating the subjects of alternative food practice. Cultural Geographies 15: 431-447.

Hancock, Claire. 2017. Feminism from the margin: Challenging the Paris/Banlieues divide. Antipode 49: 636-656.

Hannah-Jones, Nicole. 2019. 1619. Podcast. New York Times. https ://www.nytimes.com/2019/08/23/podcasts/1619-slavery-anniv ersary.html

Hantrais, L. 2008. International comparative research: Theory, methods and practice. Hampshire: Palgrave Macmillan.

Hasnaoui-Amri, Nabil. 2018. La participation des agriculteurs à une politique alimentaire territoriale: le cas de Montpellier Méditerranée Métropole. Thesis. Université Paul Valéry, Montpellier Supagro

Hayden-Smith, Rose. 2007. "Soldiers of the Soil": The work of the United States School Garden Army during World War I. Applied Environmental Education and Communication 6 (1): 19-29.

Held, Lisa. 2018. What would make urban agriculture in New York more equitable? Civil Eats. https://civileats.com/2018/03/05/ what-would-make-urban-agriculture-in-new-york-city-moreequitable/. 
Heynen, Nik, Hilda E. Kurtz, and Amy Trauger. 2012. Food justice, hunger and the city. Geography Compass 6 (5): 304-311.

Hixson, Walter. 2013. American settler colonialism: A history. New York City: Springer.

Hochedez, Camille, and Julie Le Gall. 2016. Justice alimentaire et agriculture. A critical reflection on food justice approach in the French context. Justice Spatiale/Spatial Justice, 9. https://www. jssj.org/article/justice-alimentaire-et-agriculture/. Accessed 15 November 2019.

Holt Giménez, Eric, and Annie Shattuck. 2011. Food crises, food regimes and food movements: Rumblings of reform or tides of transformation? The Journal of Peasant Studies 38 (1): 109-144.

Hoover, E. 2017. The river is in us: Fighting toxics in a Mohawk community. Minneapolis: University of Minnesota Press.

Horst, Megan. 2019. Changes in farmland ownership in Oregon, US. Land 8 (3): 39.

Horst, Megan, and Amy Marion. 2019. Racial, ethnic and gender inequities in farmland ownership and farming in the US. Agriculture and Human Values 36 (1): 1-16.

Horst, Megan, Nathan McClintock, and Lesli Hoey. 2017. The intersection of planning, urban agriculture, and food justice: A review of the literature. Journal of the American Planning Association 83 (3): 277-295.

Howard, Philip H. 2016. Concentration and power in the food system: Who controls what we eat? New York: Bloomsbury Academic.

Hugill, David. 2017. What is a settler-colonial city? Geography Compass 11: e12315.

Hurley, Patrick T., Marla R. Emery, Rebecca McLain, Melissa Poe, Brian Grabbatin, and Cari L. Goetcheus. 2015. Whose urban forest? The political ecology of foraging urban nontimber forest products. In Sustainability in the global city: Myth and practice, ed. Gary McDonogh and Melissa Checker, 187-212. New York: Cambridge University Press.

Indian Land Tenure Foundation. 2009. From removal to recovery: Land ownership in Indian Country. The Message Runner 4, Fall.

Jarosz, Lucy. 2014. Comparing food security and food sovereignty discourses. Dialogues in Human Geography 4: 168-181.

Jayaraman, Saru. 2013. Behind the kitchen door. Ithaca, NY: Cornell University Press.

King, Russell. 2019. Land reform: A world survey. London: Routledge.

Lascaux, Anne. 2019. La recomposition d'un système agricole méditerranéen au prisme des migrations, l'exemple des cultivateurs marocains dans le Comtat. Géoconfluences.

Lawson, Laura J. 2005. City bountiful: A century of community gardening in America. Berkeley, CA: University of California Press.

Loiseau, Gaëlla. 2019. Odologie et présence des gens du voyage en France: Blocages, passages et nœuds des espaces de vie voyageurs, PhD Dissertation in Sociology, University Le Havre Normandie.

Lorbek, Maja, and Milena Martinsen. 2015. Allotment garden dwellings: Exploring tradition and legal framework. Urbani izziv 26: S98-S113.

Lowe, Lisa. 2015. The intimacies of four continents. Chapel Hill, NC: Duke University Press.

Mann, Geoff. 2001. The state, race, and "wage slavery" in the forest sector of the Pacific Northwest United States. The Journal of Peasant Studies 29 (1): 61-88. https://doi.org/10.1080/71400 3939.

Maruani, Margaret, and Monique Meron. 2012. Un siècle de travail des femmes en France. La Découverte.

McClintock, Nathan. 2014. Radical, reformist, and garden-variety neoliberal: Coming to terms with urban agriculture's contradictions. Local Environment 19 (2): 147-171.
McClintock, Nathan. 2018. Urban agriculture, racial capitalism and resistance in the settler-colonial city. Geography Compass 12: e12373.

McClintock, Nathan and Christophe-Toussaint Soulard. 2018. De l'agriculture urbaine à la justice alimentaire : regards critiques franco-américains. Entretien par Flaminia Paddeu. Urbanités \#10: http://www.revue-urbanites.fr/10-mcclintock-soulard/

McClintock, Nathan, Christiana Miewald, and Eugene McCann. 2020. Governing urban agriculture: Formalization, resistance, and revisioning in two 'green' cities. International Journal of Urban and Regional Research.

McKittrick, Katherine. 2011. On plantations, prisons, and a Black sense of place. Social and Cultural Geography 12: 947-963.

McLain, Rebecca J., Melissa R. Poe, Lauren S. Urgenson, Dale J. Blahna, and Lita P. Buttolph. 2017. Urban non-timber forest products stewardship practices among foragers in Seattle, Washington (US). Urban Forestry and Urban Greening 28: 36-42.

Melamed, Jodi. 2015. Racial capitalism. Critical Ethnic Studies 1 (1): $76-85$.

Minkoff-Zern, Laura Anne, and Sea Sloatt. 2016. A new era of civil rights? Latino immigrant farmers and exclusion at the United States Department of Agriculture. Agriculture and Human Values 34 (3): 631-643.

Mihesuah, D., and E. Hoover. 2019. Indigenous food sovereignty in the United States: Restoring cultural knowledge, protecting environments, and regaining health, vol. 18. Norman: University of Oklahoma Press.

Moitt, Bernard. 2001. Women and slavery in the French Antilles, 16351848. Bloomington, IN: Indiana University Press.

Nembhard, J.G. 2014. Collective courage: A history of African American cooperative economic thought and practice. University Park, PA: Penn State Press.

Norgaard, Kari Marie. 2020. Salmon and acorns feed our people: Colonialism, natures and social action. New Brunswick: Rutgers University Press.

Omi, M., and H. Winant. 2014. Racial formation in the United States. Oxfordshire: Routledge.

Onishi, Norimitsu. 2020. George Floyd's killing forces wider debate on France's slave-trading past. New York Times. https://www. nytimes.com/2020/06/24/world/europe/france-george-floyd-racis m-slave-trade.html

Onishi, Norimitsu. 2021. Will American ideas tear France apart? Some of its leaders think so. New York Times. https://www.nytim es.com/2021/02/09/world/europe/france-threat-american-unive rsities.html

Orozco, Ashley, Alexandria Ward, and Garrett Graddy-Lovelace. 2018. Documenting USDA Discrimination: Community-partnered research on farm policy for land sustice. ACME 17 (4): 999-1023.

Paddeu, Flaminia. 2015. From urban crisis to reclaiming urban space: Grassroots environmental and food justice activism in low income neighborhoods in Detroit and the Bronx in New York. $\mathrm{PhD}$ Dissertation, Université Paris 4 Sorbonne. https://tel.archi ves-ouvertes.fr/tel-01283583

Paddeu, Flaminia. 2016. From one movement to another? Comparing environmental justice activism and food justice alternative practices. Justice Spatiale/Spatial Justice 9, https://www.jssj.org/ article/justice-alimentaire-et-agriculture/

Paddeu, Flaminia. 2019. Waste, weeds, and wild food. A critical geography of urban food collecting. EchoGéo. https://doi.org/10.4000/ echogeo.16623.

Palisse, Marianne, and Damien Davy. 2018. Different cultural approaches: Agricultural land use by indigenous people and Haitian migrants in French Guiana. Etudes Rurales 2: 158-177. 
Penniman, Leah. 2018. Farming while black: Soul Fire Farm's practical guide to liberation on the land. Hartford, Vermont: Chelsea Green Publishing.

Perrin, Coline and Adrien Baysse-Lainé. 2020. Governing the coexistence of agricultural models. French cities allocating farmlands to support agroecology and short food chains on urban fringes. Review of Agricultural, Food and Environmental Studies.

Perrin, Coline, and Brigitte Nougaredes. Forthcoming. An analytical framework to consider social justice issues in farmland preservation on the urban fringe. Journal of Rural Studies.

Poe, Melissa R., Joyce LeCompte, Rebecca McLain, and Patrick Hurley. 2014. Urban foraging and the relational ecologies of belonging. Social and Cultural Geography 15: 901-919.

Porter, L., J. Hurst, and T. Grandinetti. 2020. The politics of greening unceded lands in the settler city. Australian Geographe. https:// doi.org/10.1080/00049182.2020.1740388.

Poulin, Richard. 1992. CLR James: Croquis d'un nationaliste marxiste noir. Canadian Ethnic Studies. 24 (2): 77.

Pourias, Jeanne, Christine Aubry, and Eric Duchemin. 2016. Is food a motivation for urban gardeners? Multifunctionality and the relative importance of the food function in urban collective gardens of Paris and Montreal. Agriculture and Human Values 33 (2): 257-273.

Prasad, M. 2005. Why is France so French? Culture, institutions, and neoliberalism, 1974-1981. American Journal of Sociology 111 (2): 357-407.

Pulido, Laura. 2017. Geographies of race and ethnicity II: Environmental racism, racial capitalism and state-sanctioned violence. Progress in Human Geography 41: 524-533.

Pulido, Laura. 2018. Geographies of race and ethnicity III: Settler colonialism and nonnative people of color. Progress in Human Geography 42 (2): 309-318.

Reese, Ashanté M. 2019. Black food geographies: Race, Self-reliance, and food access in Washington. Chapel Hill, NC: University of North Carolina Press.

Reynolds, Bruce J. 2002. Black farmers in the pursuit of independent farming and the role of cooperatives. Washington, DC: USDA Rural Business Cooperative.

Reynolds, Kristin. 2015. Disparity despite diversity: Social injustice in New York City's urban agriculture system. Antipode 47 (1): 240-259.

Reynolds, Kristin. 2019. Realizing a comprehensive urban agriculture plan in New York City?Perspectives on Int. No. 1058-2018: A local law in relation to developing acomprehensive urban agriculture plan. CUNY Urban Food Policy Institute. https://www. cunyurbanfoodpolicy.org/news/2019/6/20/realizing-a-compr ehensive-urban-agriculture-plan-in-new-york-city. Accessed 30 November 2019.

Reynolds, Kristin. 2020. Food, agriculture, and environmental justice perspectives on scholarship and activism in the field. In Environmental justice: Key issues, ed. B. Coolsaet. New York: Routledge.

Reynolds, Kristin, and Nevin Cohen. 2016. Beyond the kale: Urban agriculture and social justice activism in New York City. Athens, GA: University of Georgia Press.

Reynolds, Kristin, and Ségolène Darly. 2018. Commercial urban agriculture in the global city: Perspectives from New York City and Métropole du Grand Paris. CUNY Urban Food Policy Institute. http://www.cunyurbanfoodpolicy.org/news/2018/12/11/lscislvsr7 spj7834v91s796n6xm7h. Accessed 30 November 2019.

Robert, P. 1996. Dictionnaire de la langue française. Paris: Dictionnaires Le Robert.

Robinson, Cedric. 2000. Black Marxism: The making of the Black radical tradition. Chapel Hill, NC: University of North Carolina Press.
Safransky, Sara. 2014. Greening the urban frontier: Race, property, and resettlement in Detroit. Geoforum 56: 237-248.

Safransky, Sara. 2018. Land justice as a historical diagnostic: Thinking with Detroit. Annals of the American Association of Geographers 108 (2): 499-512.

Saurugger, S. 2007. Democratic 'misfit'? Conceptions of civil society participation in France and the European Union. Political Studies 55 (2): 384-404.

Sbicca, Joshua. 2015. Food labor, economic inequality, and the imperfect politics of process in the alternative food movement. Agriculture and Human Values 32 (4): 675-687.

Sbicca, Joshua. 2018. Food justice now!: Deepening the roots of social struggle. Minneapolis: University of Minnesota Press.

Sbicca, J. 2019. Urban agriculture, revalorization, and green gentrification in Denver, Colorado. In The politics of land. Bingley: Emerald Publishing Limited.

Sencébé, Yannick. 2012. La Safer. De l'outil de modernisation agricole à l'agent polyvalent du foncier: hybridation et fragmentation d'une institution (SAFER (Land Development and Rural Establishment Companies)). Terrains and Travaux 20 (1): 105-120.

Shackleton, Charlie, Patrick Hurley, Annika Dahlberg, Marla Emery, and Harini Nagendra. 2017. Urban foraging: A ubiquitous human practice overlooked by urban planners, policy, and research. Sustainability 9 (10): 1884.

Shoemaker, Jessica. 2003. Like snow in the spring time: Allotment, fractionation, and the Indian land tenure problem. Wisconsin Law Review 729.

Simpson, Leanne B. 2017. As we have always done: Indigenous freedom through radical resistance. Minneapolis: University of Minnesota Press.

Simpson, Michael, and Jen Bagelman. 2018. Decolonizing urban political ecologies: The production of nature in settler colonial cities. Annals of the American Association of Geographers 108: 558-568.

Slocum, Rachel, Kirsten Valentine Cadieux, and Renata Blumberg. 2016. Solidarité, espace et race: vers des géographies de la justice alimentaire. Justice Spatiale Spatial Justice.

Smit, Jac, Joe Nasr, and Annu Ratta. 1996. Urban agriculture: Food, jobs and sustainable cities. New York: The Urban Agriculture Network.

Smith, Jac, and Petr Jehlička. 2013. Quiet sustainability: Fertile lessons from Europe's productive gardeners. Journal of Rural Studies 32: $148-157$.

Soulard, Christophe. 2014. Les agricultures nomades, une caractéristique du périurbain. Pour 2014/4(224): 151-158

Stoler, Ann Laura. 2011. Colonial aphasia: Race and disabled histories in France. Public Culture 23: 121-156.

Svizzero, Serge. 2016. Foraging wild resources: Evolving goals of an ubiquitous human behavior. Anthropology 4: 1-9.

Synk, Colleen M., Brent F. Kim, Charles A. Davis, James Harding, Virginia Rogers, Patrick T. Hurley, Marla R. Emery, and Keeve E. Nachman. 2017. Gathering Baltimore's bounty: Characterizing behaviors, motivations, and barriers of foragers in an urban ecosystem. Urban Forestry and Urban Greening 28: 97-102.

Tornaghi, Chiara, and Chiara Certomà, eds. 2018. Urban gardening as politics. New York: Routledge.

Tsing, Anna Lowenhaupt. 2015. The mushroom at the end of the world: On the possibility of life in capitalist ruins. Princeton, NJ: Princeton University Press.

United States Department of Agriculture. 2017. Farming and Farm Income: https://www.ers.usda.gov/data-products/ag-and-foodstatistics-charting-the-essentials/farming-and-farm-income/ Accessed 15 November 2019.

van der Ploeg, Jan, Jennifer Franco Douwe, and Saturnino Borras. 2015. Land concentration and land grabbing in Europe: A 
preliminary analysis. Canadian Journal of Development Studies 36 (2): 147-162.

von Hoffen, Laura Pailin., and Ina Säumel. 2014. Orchards for edible cities: Cadmium and lead content in nuts, berries, pome and stone fruits harvested within the inner city neighbourhoods in Berlin, Germany. Ecotoxicology and Environmental Safety, 101: 233-239.

Walker, Richard. 2004. Conquest of bread. New York: New Press.

Weber, Florence. 1998. Honneur des jardiniers. Paris, Éditions Belin (socio-histoires): Les Potagers dans la France du XXe siècle.

White, Monica. 2018. Freedom farmers: Agricultural resistance and the Black Freedom Movement. Chapel Hill, NC: University of North Carolina Press.

Williams, Justine, and Eric Holt-Giménez. 2017. Land justice: Reimagining land, food, and the commons. Boston, MA: Food First Books.

Wood, Spencer, and Jess Gilbert. 2000. Returning African American farmers to the land: Recent trends and a policy rationale. The Review of Black Political Economy 27 (4): 43-64.

Publisher's Note Springer Nature remains neutral with regard to jurisdictional claims in published maps and institutional affiliations.

Megan Horst Ph.D., is Assistant Professor in the Nohad A. Toulan School of Urban Studies and Planning at Portland State University. She received her masters and $\mathrm{Ph}$.D. in urban planning from the University of Washington. Her research and teaching focuses on food justice, food systems planning, urban agriculture, farmland access and ownership, and land use planning.

Nathan McClintock Ph.D., is Associate Professor in the Nohad A. Toulan School of Urban Studies and Planning at Portland State University and editor of the journal Urban Geography. He received his $\mathrm{PhD}$ in geography from UC Berkeley and MS in agroecology from North Carolina State University. His research and teaching focuses on urban agriculture and food justice, food systems planning, urban political ecology, and critical urban theory.

Adrien Baysse-Lainé Ph.D., is Lecturer in the Teaching Center on Environment and Society of École Normale Supérieure, at Université PSL. He received his Ph.D. in geography and planning from the Université de Lyon. His research focuses on farmland access, legal geography, food relocalization and the soils/land nexus.
Ségolène Darly is Tenured Lecturer at the Geography department of the University Paris 8 Vincennes Saint-Denis, France and member of the LADYSS-Social dynamics and Spatial Recompositions research unit. She received her Ph.D. in geography from EHESS (Paris, France) in 2009 and MS in agronomy sciences from AgroParisTech (France). Her research and teaching deals with land-use conflicts, farm land managment, urban agriculture, land-use planning and food system social geography.

Flaminia Paddeu Ph.D., is Assistant Professor at Sorbonne Paris Nord University. She received her masters and Ph.D. in geography and urban planning from the Ecole Normale Supérieure of Lyon and from Paris Sorbonne University. Her research and teaching focuses on alternative food systems, environmental and food justice, urban food collecting and urban agriculture.

Coline Perrin is Senior Researcher at INRAE (The French National Institute for Research in Agriculture, Food, and the Environment), Montpellier, France. She received her Ph.D. in Geography and Urban Planning from Aix-Marseille University (France) and Florence University (Italy). Her research focuses on food systems planning, urban agriculture, farmland access and ownership, and land use planning, in France, Italy and other Mediterranean countries.

Kristin Reynolds Ph.D. is an independent scholar in New York City; Lecturer in Food Studies and Environmental Studies programs at The New School; and Lecturer at Yale School of Forestry and Environmental Studies. She earned her Ph.D. in geography and MS in International Agricultural Development from the University of California, Davis. Her work focuses on food systems and environmental justice; urban agriculture; and geographic dimensions of food justice scholar-activism/activist-scholarship.

Christophe-Toussaint Soulard is Senior Researcher (Ph.D. and HDR) in the UMR Innovation at the French National Institute of Research in Agriculture, Food, and the Environment. He received his $\mathrm{PhD}$ in human geography from the University of Paris Panthéon-Sorbonne. His research focuses on urban agriculture and food policies, comparing France and Mediterranean countries. In 2017 and 2018, he has been visiting scholar in the Nohad A. Toulan School of Urban Studies and Planning at Portland State University, working on urban agriculture and food justice in the USA. 